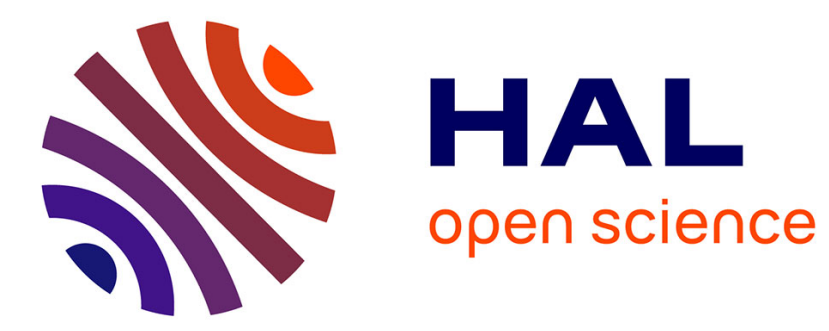

\title{
A locust witness of a trans-oceanic Oligocene migration between Arabia and Iran (Orthoptera: Acrididae)
}

\author{
Majid Mirzaie Ataabadi, Ali Bahrami, Mehdi Yazdi, André Nel
}

\section{To cite this version:}

Majid Mirzaie Ataabadi, Ali Bahrami, Mehdi Yazdi, André Nel. A locust witness of a trans-oceanic Oligocene migration between Arabia and Iran (Orthoptera: Acrididae). Historical Biology, 2019, 31 (5), pp.574-580. 10.1080/08912963.2017.1378651 . hal-02181688

\section{HAL Id: hal-02181688 \\ https://hal.sorbonne-universite.fr/hal-02181688}

Submitted on 12 Jul 2019

HAL is a multi-disciplinary open access archive for the deposit and dissemination of scientific research documents, whether they are published or not. The documents may come from teaching and research institutions in France or abroad, or from public or private research centers.
L'archive ouverte pluridisciplinaire HAL, est destinée au dépôt et à la diffusion de documents scientifiques de niveau recherche, publiés ou non, émanant des établissements d'enseignement et de recherche français ou étrangers, des laboratoires publics ou privés. 


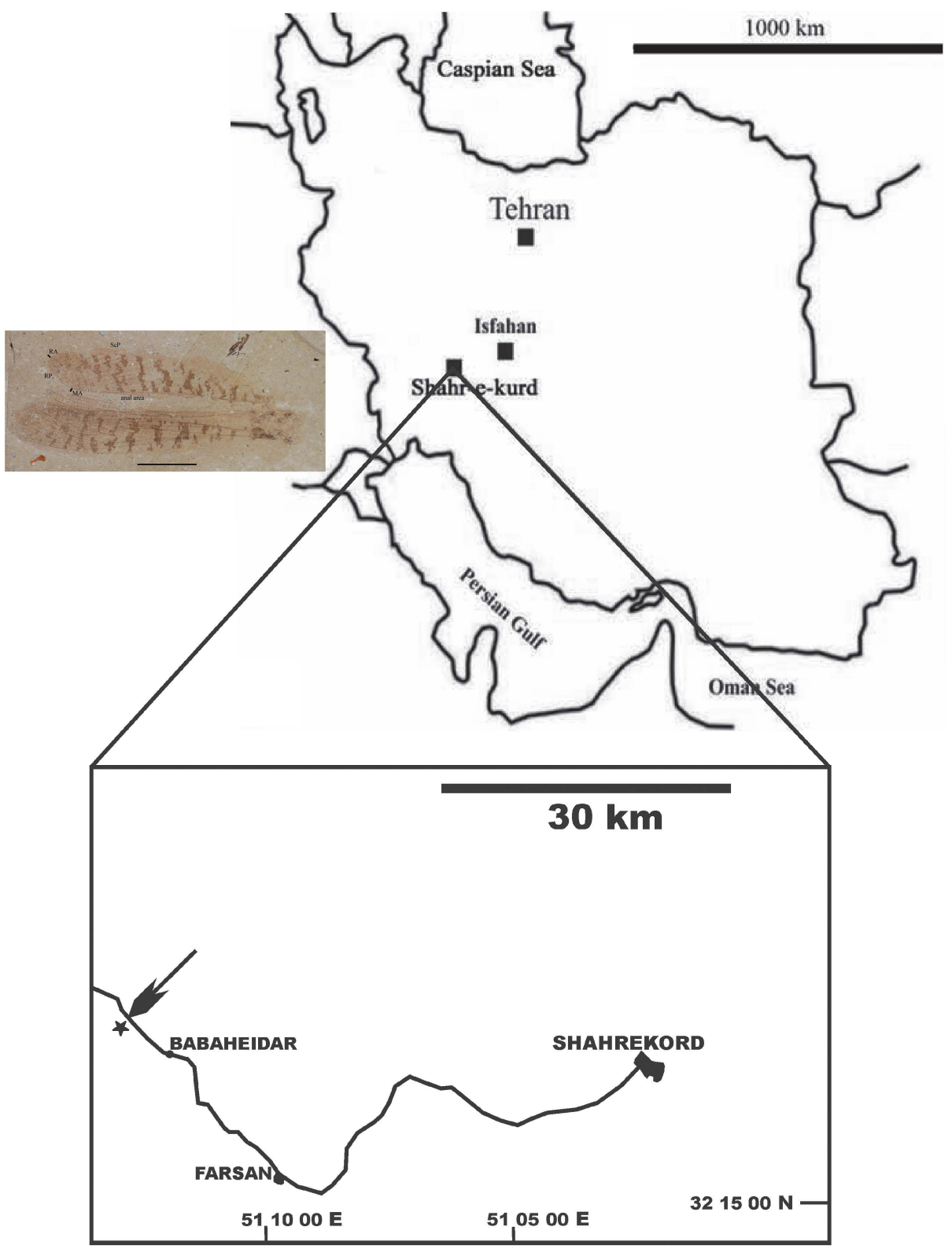


A locust witness of a trans-oceanic Oligocene migration between Arabia and Iran

(Orthoptera: Acrididae)

Majid Mirzaie Ataabadi ${ }^{\mathrm{a}}$, Ali Bahrami ${ }^{\mathrm{b}}$, Mehdi Yazdi ${ }^{\mathrm{b}}$ and André $\mathrm{Nel}^{\mathrm{c}, *}$

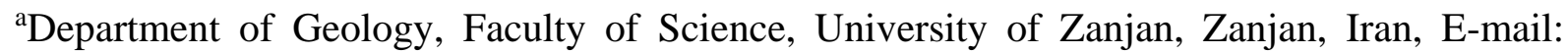
majid.mirzaie@znu.ac.ir; ${ }^{b}$ Department of Geology, Faculty of Science, University of Isfahan, Isfahan, Iran. E-mail: a.bahrami@sci.ui.ac.ir, m.yazdi@sci.ui.ac.ir; 'Institut de Systématique, Évolution, Biodiversité, ISYEB - UMR 7205 - CNRS, MNHN, UPMC, EPHE, Muséum national d’Histoire naturelle, Sorbonne Universités, 57 rue Cuvier, CP 50, Entomologie, F75005, Paris, France. E-mail: anel@mnhn.fr

\begin{abstract}
Fossil insects are very rarely found in sediments of deep marine origin. Nevertheless they can be of great interest to trace past events such as trans-oceanic migrations. Here we document the first fossil insects from Iran, viz. several alate ants dead during mating swarms and a migratory locust, found in the pelagic Oligocene sediments of the Zagros Mountains. This locust represents the first putative indication of insect migrations between the Arabian-African and Asiatic continents through the Parathetys, probably in relation with the development of open grassland biotas in these areas.
\end{abstract}

\title{
KEYWORDS
}

Insecta; Acrididae; Formicidae; putative migration; Oligocene; Parathetys; Iran 


\section{Introduction}

Direct fossil evidence of a long-distance mass insect migration are extremely rare. One record is known for a moth migration in the diatomous sediments of the Fur Formation from the Early Paleogene of Denmark (55 million years old) (Rust 2000). The main reason of the rarity of such evidences is that insects need to be fossilized in marine sediments. The discovery of numerous fossils of the same species in the same layer of a terrestrial deposit can correspond to a continental migration but also to a local mass occurrence. For instance, several griffenflies were found in one layer of the Middle Permian of Lodève (France) but it is not possible to say that they correspond to a migration (Nel et al., 2008). Arillo \& Ortuño (1997), on the basis of the numerous co-occurrences of locusts fossilized in the same Spanish Oligocene paleolake, hypothesized that they could correspond to an evidence of gregarious behavior, but they could not infer a phenomenon of mass migration. Insect taphocoenosis of marine origin are not very frequent. Notable exceptions are the Early Triassic of Australia (Haig et al. 2015), Early Jurassic of Northern Europe (Ansorge 1996), Late Jurassic of Germany (Viohl 1996) and France (Nel et al. 2014), Early Cretaceous of Lebanon (Nel et al., 2004; Vršanský \& Makhoul 2013), and Early Paleogene of D enmark (Rust, 1998). These relatively rich outcrops correspond to relatively shallow water, frequently lagoonal, paleoenvironments close to land masses. Sediments of pelagic origin normally do not contain fossil insects, with the exceptions of a beetle elytron found in Paleocene flysch sediments produced in the lower bathyal to abyssal zone of Moravia (Prokop et al. 2004), and the recent discovery of a fly found in the deep-water marine Early Miocene of Zillerleite, Germany (Nel, pers. obs.). Here we record the first fossil insects from Iran, viz. remnants of ants and of the wings of a locust, found by one of us (MMA) in the pelagic Oligocene sediments of the Zagros Mountains. This locust probably died during a migration between the Arabian Peninsula and the continental Iran. Although fossil insects were known from these fossil beds (Garassino et al. 2014), none 
of them was studied. Otherwise only traces of insect activities are putatively known from Iran, viz. Vaez-Javadi (2006: pl. 2, fig. 1) figured fossil leaves with possible arthropod margin traces of activity from the Rhaetian of NE Iran; and Ameri et al. (2014: figs 3-4) figured Middle Jurassic leaves with possible traces of activity on their margins. Dating and palaeoenvironmental conditions for the oldest migrations of locusts between Africa, Europe and Asia are discussed.

\section{Material and methods}

Babaheidar (Babaheydar) is a small town located in Chahar Mahal and Bakhtiari province in west central Iran. It is ca. $50 \mathrm{~km}$ from Shahrekord, the capital city of the province (Fig. 1). The area is mostly located in the high Zagros mountain ranges. Numerous marine deposits ranging from late Paleozoic to the end of Cenozoic were found in the area. The 'Konservat Lagerstätte' of Babaheidar was discovered about three decades ago during the construction of a road. The fauna was preliminary reported (Jafarian 1990), but has not been studied systematically until later (Jafarian et al. 1999). Recent field researches by teams from the University of Isfahan have given thousands of fishes but also plants, crustaceans, insects, and birds (Tyler et al. 2006; Garassino et al. 2014). The fossil beds of Babaheidar area belong to the Pabdeh Formation, deposited in the north-western and southern parts of the Zagros Basin mainly during the Eocene and in some areas until the Oligocene and even the Miocene. It mainly consists of white marls, dark to light grey shales rich in planktonic microfauna, and thin to thick-bedded marl limestones (platy limestone) which preserved the macrofauna (Garassino et al. 2014). It is about 800 meters thick in the studied area. The Pabdeh Formation is covered by the famous Oligocene/Miocene beds of the Asmari Formation, and it rests on the Eocene terrigenous red deposits of the Kashkan Formation. (Fig.2). 
The sedimentary environment of the Pabdeh Formation based on several studies (microfacies and trace fossil analyses, sedimentary petrology, and micropaleontology) indicates a deep sea environment (upper bathyal zone). The abundance of micrites, glauconite, planktonic foraminifera, fish fauna, and the presence of a pelagic bird support a palaeoenvironment of pelagic marine origin (Paratethys) (Aqrawi et al. 2006; Amirshahkarami et al. 2007; Mohseni et al. 2011; Garassino et al. 2014).

Deposits of the Pabdeh Formation are generally assigned to the Eocene age. However, a study of the nanoplanktons and planktonic foraminifera from one section in the Babaheidar area, in which the pelagic bird was found (Peters and Hamedani 2000), indicated that the studied section is Rupelian (early Oligocene) in age (Hamrsmid \& Rogl 2000). Nevertheless, a recent study of the planktonic microfauna from the other sections indicates a middle to late Eocene age (Garassino et al. 2014). It is quite possible that the very thick Pabdeh Formation covers a period ranging from the late Eocene to the early Oligocene. The fossil fishes as well as the other fauna are present at several intervals, though they are not abundant in the lower parts.

The fossil insects from Babaheidar area come from several localities. The exact stratigraphic position for some of them is unclear. However, the Orthoptera comes from the upper parts of the succession, early Oligocene in age. It is likely that other insects also come from these intervals because it is the most investigated part of the series for the fossil fishes that are frequently found in these layers.

The studied specimens are housed in the Palaeontological Collection of the Department of Geology, University of Isfahan, I.R. Iran (UIDG). The fossils were photographed with a Nikon D40X. We follow the wing venation terminology of Béthoux and Nel (2002). R, radial vein; RP posterior branch of R; M median vein; CuA anterior branch of cubital vein; CuP posterior branch of cubital vein. 


\section{Systematic palaeontology}

Class Insecta Linnaeus, 1758

Order Orthoptera Olivier, 1789

Family Acrididae MacLeay, 1819

Subfamily, Genus and species undetermined

(Figs 3-4)

Material. Specimen IUDG 16 (two tegmina and a hindwing attached to fragments of the thorax).

Occurrence. Rupelian, Oligocene, Pabdeh Formation (zone NP 24), Sepid danehKavanak, high Zagros Mountains near the town of Babaheidar (Baba Heydar), western Iran.

\section{Description}

Tegmen hyaline, with ca. 11 irregular brown transverse stripes, large, $67.0 \mathrm{~mm}$ long, $11.3 \mathrm{~mm}$ wide, falcate with apex cut; subcostal area $2.0 \mathrm{~mm}$ wide; no visible intercalary longitudinal vein (i.l.v.) in area between $\mathrm{R}+\mathrm{M}+\mathrm{CuA}$ and $\mathrm{CuP}$; $\mathrm{RP}$ with ten branches and intercalary longitudinal veins between them; anal veins very long, closely parallel, ending on posterior wing margin ca. 49.0 $\mathrm{mm}$ from wing base and $17.3 \mathrm{~mm}$ from wing apex; anal area with several rows of very small cells; CuP ending on first anal vein; hindwing large but covered by a tegmen and very poorly preserved, hyaline.

\section{Discussion}

The presence of very long anal veins on the tegmen, distally fused with $\mathrm{CuPb}$ near posterior wing margin is a character only present in some caeliferan groups (Pauliniidae, Charilaidae, some Catantopidae, and mainly Acrididae) (Dirsh 1975). Among these groups, only some Acrididae have so numerous branches of RP (10 branches) and a similar shape of tegmen 
elongate, falcate, and with a cut apex (e.g. Cyrtacanthacridinae, Calliptaminae, and Oedipodinae) (Dirsh 1961, 1965). The absence of the intercalary longitudinal vein in the area between $\mathrm{R}+\mathrm{M}+\mathrm{CuA}$ and $\mathrm{CuP}$ would exclude affinities with the Oedipodinae. The particular ornamentation of the tegmen with more than 11 transverse dark zones can be found in these subfamilies but also in some Acridinae. The pattern of venation and of ornamentation is very similar to that of the modern Schistocerca gregaria (Forskål, 1775) or Locusta migratoria Linnaeus, 1758, but also of species in the genera Aiolopus Fieber, 1853, or Oedaleus Fieber, 1853, etc. (Fard 1990; Garai 2010). It is impossible on the sole basis of the wing venation to attribute this fossil to a precise tribe or genus, even if an attribution to the Cyrtacanthacridinae could be the most probable for the great similarity of tegmen with Schistocerca gregaria.

The great similarity of this fossil in size of wings, tegmen shape, venation, and ornamentation with those of a Schistocerca or a Locusta suggests that this insect had flight capacities similar to those of these migratory locusts. Even its long tegmina suggest that it was a long-winged morph able to migrate, unlike the short-winged morph of Locusta migratoria (Nishide \& Tanaka 2013). Brown versus green color can have also an impact on the migratory behavior in these locusts (Cease et al. 2010), but, even if the tegmina of this fossil are colored in brown, it is not possible to be sure that it is the original color of the insect because chemical green colors of insects degrade into brown color during taphonomic process (McNafihis,läulist).was certainly an active flyer because of the large dimensions and shape of the tegmina. Locusts are known to occur at high altitude during their migration (Berland 1937), and to cross over seas and oceans. After its discovery in deep water sediments of the Oligocene Thetys together with its flight capacities, we can infer that it died in open sea and went in deep water sometime after its death because it was obviously dislocated as it only shows fragments of thorax with two forewings and one hindwing. Experiments on modern Orthoptera showed that these insects, when they arrive at the water surface, float for a long time and generally 
dislocate before sinking (Popov 1959; Wilson 1980; Nel 1991; Martínez-Delclòs \& Martinell 1993). The eutrophication in the photic zone of the ancient sea with bloom of nannoplankton (Hamrsmid \& Rögl, 2000) favored its sinking and fossilization (Nel 1991; Paicheler et al. 2007).

The other insects found in the Pabdeh Formation are small ants (alate males and females Formicidae, 3-5 mm long) (Fig. 5). They were found in the Qanbar Siny section of Babaheidar area. Such ants are flying during their mating swarm. They were lost in the sea. They have also lost body parts (wings, legs, heads or abdomens) and probably stayed a long time on the water surface before sinking.

The concerned area was occupied during the Oligocene by the rather broad Paratethys between the Arabian Peninsula and Central Iran (Rögl 1998). It is possible to suppose that this locust participated to a migration event between these two lands, similarly to what happens nowadays, covering longer distance than the width of the Oligocene Paratethys between Arabia and Iran (Cressman 1998). The Eocene-Oligocene climate is considered rather dry in the concerned area and more generally in Asia (Dupont-Nivet et al. 2007; Soleimani 2009), fitting well to the presence of migratory locusts living in open grasslands. The cooling and drying of Asian climate at the Eocene-Oligocene boundary caused a turnover of the mammal fauna and flora from a 'perissodactyl-dominant fauna in forests under a warm-temperate climate to small rodent/lagomorph-dominant fauna in a forest-steppe' (Sun et al. 2014). Arabian-Asiatic migrations of locusts could have been initiated and/or favored by these climatic changes during the late Paleogene.

More generally it seems that the Acrididae began to diversify only during the Oligocene, maybe also in relation to the development of more open biotas. Fossil Acrididae are very scarce and only known since the late Eocene (Gorochov \& Rasnitsyn 2002). The oldest alleged Acrididae, Menatacridium Piton, 1936 from the Paleocene of France, has been discussed by 
Zeuner (1944) who concluded that its position is unclear. Compression fossils of Acrididae become slightly more frequent in the lacustrine outcrops of the late Oligocene and the Miocene.

\section{Conclusions}

No other record of Iranian fossil insects is known. Further field researches will be necessary to increase our knowledge on the past entomofauna from this country. Such discoveries could be of great interest as direct evidences on the biogeography of this area situated between Africa and Asia. Also, it appears that fossil insects could be more frequent than expected in outcrops of deep marine origin. They could be of great interest to trace ancient behaviors such as intercontinental migrations.

\section{Acknowledgements}

We sincerely thank Pr Bo Wang and an anonymous referee for their very useful comments on the first version of the paper. MMA thanks Erfan Khosravi (University of Tehran) and Borzu Asgari (Islamic Azad University, Masjed Soleiman) for their support during the field work.

\section{Disclosure statement}

No potential conflict of interest was reported by the authors.

\section{References}

- Ameri H., Dastanpour M., Khalilizade H., Zamani F., 2014. Plant fossil remains from the Bajocian-Bathonian of Hojedk Formation, Babhutk area, Kerman, Iran. Arabian Journal of Geoscience 7:2293-2302. 
- Amirshahkarami M., Vaziri-Moghaddam H., Taheri A. 2007. Sedimentary facies and sequence stratigraphy of the Asmari Formation at Chaman-Bolbol, Zagros basin, Iran. Journal of Asian Earth Sciences 29:947-959.

- Ansorge J. 1996. Insekten aus dem Oberen Lias von Grimmen (Vorpommern, Norddeutschland). Neue Paläontologische Abhandlungen 2:1-132.

- Aqrawi A.A.M., Keramati M., Ehrenberg S.N., Pickard N., Moallemi A., Svånå T., Darke G., Dickson J.A.D., Oxtoby N.H. 2006. The origin of dolomite in the Asmari Formation (Oligocene-Lower Miocene), Dezful Embayment, SW Iran. Journal of Petroleum Geology 29:381-402.

- Arillo A., Ortuño V.M. 1997. The fossil Acrididae from the Oligocene of Izarra (Alava, Spain). The antiquity of gregarious behavior (Orthoptera: Caelifera). Geobios 30:231234.

- Berland L. 1937. Données récentes sur le transport aérien d'animaux et de plantes, d'après des recherches faites en avion. Comptes Rendus de la Société de Biogéographie $14: 25-28$.

- Cease A.J., Hao Shuguang, Kang, Le, Elser J.J., Harrison J.F. 2010. Are color or high rearing density related to migratory polyphenism in the band-winged grasshopper, Oedaleus asiaticus? Journal of Insect Physiology 56:926-936.

- Cressman K. 1998. Monitoring desert locusts in the Middle East: an overview. Bulletin Series, Yale School of Forestry and Environmental Studies 103:123-140.

- Dirsh V.M. 1961. A preliminary revision of the families and subfamilies of Acridoidea (Orthoptera). Bulletin of the British Museum, (Natural History), Entomology 10:351419.

- $\quad$ Dirsh V.M. 1965. The African genera of Acridoidea (Orthoptera). Cambridge:579 pp. 
- Dirsh V.M. 1975. Classification of the acridomorph insects. Classey, E.W. (publ.), Oxford:v-vii + 1-171.

- Dupont-Nivet G., Krijgsman W., Langereis C.G., Abels H.A., Dai Shuang, Fang Xiaomin 2007. Tibetan plateau aridification linked to global cooling at the EoceneOligocene transition. Nature 445:635-638.

- Fard P.A. 1990. Investigations on the band-winged grasshoppers Oedipodinae of Iran. Boletin de Sanidad Vegetal, Fuera de Serie 20:145-150.

- Fieber, F.X. 1853. Synopsis der europäischen Orthoptera. Lotos, Zeitschrift für Naturwissenschaften, 3:90-104.

- Forskål, P. 1775. Descriptiones Animalium Avium, Amphibiorum, Piscium, Insectorum, Vermium; quae in Itinere Orientall observati Petrus Forskal. Prof. Haun. Post morten Acutoris editt Carsten Nieburhr:1-164.

- Garai G. 2010. Contribution to the knowledge of the Iranian orthopteroid insects I. Esperiana 15:393-417.

- Garassino A., Bahrami A., Yazdi M., Vega F.J. 2014. Report on decapod crustaceans from the Eocene of Zagros Basin, Iran. Neues Jahrbuch fur Geologie und Palaontologie, Abhandlungen 274:43-54.

- Gorochov A.V., Rasnitsyn A.P. 2002. Superorder Gryllidea Laicharting, 1781 (= Orthopteroidea Handlirsch, 1903). pp. 293-304. In: Rasnitsyn A.P., Quicke D.L.J. (eds). 2002. History of insects. Kluwer Academic Publishers, Dordrecht, Boston, London:xi $+517 \mathrm{pp}$.

- Haig D.W., Martin S.K., Mory A.J., McLoughlin S., Backhouse J., Berrell R.W., Kear B.P., Hall R., Foster C.B., Shi Guang R., Bevan J.C. 2015. Early Triassic (early Olenekian) life in the interior of East Gondwana: mixed marine-terrestrial biota from 
the Kockatea Shale, Western Australia. Palaeogeography Palaeoclimatology Palaeoecology 417:511-533.

- Hamrsmid B., Rögl F. 2000. Biostratigraphy of the Baba Heydar section, Iran. Senckenbergiana Lethaea 80:39-44.

- Jafarian M.A. 1990. Preliminary investigation and systematic of Eocene fish from Bakhtiari region. Abstracts of the $9^{\text {th }}$ Geoscience meeting, Geological Survey of Iran.

- Jafarian M.A, Samani P.B., Ghobadipour M. 1999. Investigation and introduction of some Eocene fish fossils in Zagros Basin. University of Isfahan Journal (Science) 13:181-196 (in Persian).

- Linnaeus, C. von 1758. Systema Naturae per regna tria naturae secundum classes, ordines, genera, species cum characteribus, differentiis, synonymis, locis. Ed. decima reformata. Holmiae, Laur. Salvii, 1:1-823.

- Martínez-Delclòs X., Martinell J. 1993. Insect taphonomy experiments. Their application to the Cretaceous outcrops of lithographic limestones from Spain. Kaupia, Darmstädter Beiträge zur Naturgeschichte 2:133-144.

- McNamara, M.E. 2013. The taphonomy of colour in fossil insects and feathers. Palaeontology 56:557-575.

- Mohseni H., BehBahani R., KhodaBaKhsh S., Atashmard Z. 2011. Depositional environments and trace fossil assemblages in the Pabdeh Formation (Paleogene), Zagros Basin, Iran. Neues Jahrbuch fur Geologie und Palaontologie, Abhandlungen 262:59_ 77.

- Nel A. 1991. Analyse d'entomofaunes cénozoiques. Intérêt de la Paléoentomologie pour les Sciences de la Terre et de la Vie. Thèse de Doctorat (nouveau régime), Université de Reims-Champagne-Ardenne. Soutenue le 13. 12. 1991:1-882. 
- Nel A., Fleck G., Garrouste R., Gand G. 2008. The Odonatoptera of the Late Permian Lodève Basin (Insecta). Journal of Iberian Geology 34:115-122.

- $\quad$ Nel A., Nel P., Krieg-Jacquier R., Pouillon J.-M., Garrouste R. 2014. Exceptionally preserved insect fossils in the Late Jurassic lagoon of Orbagnoux (Rhône Valley, France). PeerJ 2 (e510):1-16.

- Nishide Y., Tanaka S. 2013. Wing dimorphism in the migratory locust, Locusta migratoria: differentiation of wing morph and phase polyphenism. Entomological Science 16:421-431.

- Paicheler J.-C., Nel A., Gall J.-C., Delclòs X. 2007. The aquatic genus Notonecta (Insecta: Heteroptera) as a palaeo-ecological indicator of rhythmite miming sequences in shallow freshwater deposits. Journal of Taphonomy 5:105-120.

- Peters D.S., Hamedani A. 2000. Frigidafons babaheydariensis n. sp., ein Sturmvogel aus dem Oligozän des Irans (Aves: Procellariidae). Senckenbergiana Lethaea 80:29-37.

- Popov G. 1959. The desert locust (Schistocerca gregaria Forskål) in the Island of Socotra. Journal of Animal Ecology 28:89-95.

- Prokop J., Nel A., Hajek J., Bubik M. 2004. First record of a fossil beetle (Coleoptera, Haliplidae) from the base of Paleocene flysch sediment in the Magura unit (Outer Western Carpathians, Moravia). Geologica Carpatica 55:469-473.

- Rögl F. 1998. Palaeogeographic considerations for Mediterranean and Paratethys seaways (Oligocene to Miocene). Annalen des Naturhistorischen Museums in Wien (A) 99:279-310.

- Rust, J. 1998. Biostratinomie von Insekten aus der Fur-Formation von Dänemark (Moler, oberes Paleozän/unteres Eozän) [Biostratinomy of insects from the Fur 
Formation of Denmark (Moler, Upper Paleocene / Lower Eocene).] Paläontologische Zeitschrift, 72: 41-58.

- Rust J. 2000. Fossil record of mass moth migration. Nature 405:530-531.

- Soleimani B. 2009. Paleoclimate reconstruction during Pabdeh, Gurpi, Kazhdumi and Gadvan Formations (Cretaceous-Tertiary) based on clay mineral distribution. International Journal of Civil and Environmental Engineering 1:59-63.

- $\quad$ Sun Jimin, Ni Xijun, Bi Shundong, Wu Wenyu, Ye Jie, Meng Jin, Windley B.F. 2014. Synchronous turnover of flora, fauna, and climate at the Eocene-Oligocene boundary in Asia. Nature Scientific Report 4 (7463):1-6.

- $\quad$ Tyler J.C., Mirzaie M., Nazemi A. 2006. New genus and species of basal tetraodontoid puffer fish from the Oligocene of Iran, related to the Zignoichthyidae (Tetraodontiformes). Bollettino del Museo Civico di Storia Naturale di Verona, Geologia Paleontologia Preistoria 30:49-58.

- Vaez-Javadi F. 2006. Plant fossil remains from the Rhaetian of Shemshak Formation, Narges-Chal area, Alborz, NE Iran. Rivista Italiana di Paleontologia e Stratigrafia 112:397-416.

- Viohl G. 1996. The paleoenvironment of the Late Jurassic fishes from the Southern Franconian Alb. pp. 513-528. In: Arralia G., Viohl G. (eds). Mesozoic fishes. Systematics and Paleoecology, Verlag, München.

- Vršanský P., Makhoul E. 2013. Mieroblattina pacis gen. et sp. n. - Upper Cretaceous cockroach (Blattida: Mesoblattinidae) from Nammoura limestone of Lebanon. pp. 167172. In: Azar D., Engel M.S., Jarzembowski E., Krogmann L., Nel A., Santiago-Blay J. (eds). Insect Evolution in an Amberiferous and Stone Alphabet. Proceedings of the 6th International Congress on Fossil Insects, Arthropods and Amber. 
- Wilson, M.V.H. 1980. Eocene lake environments: depth and distance-from-shore variation in fish, insect and plant assemblages. Palaeogeography, Palaeoclimatology, Palaeoecology 32:21-44.

- Zeuner F.E. 1944. The fossil Acrididae (Orth. Salt.). - Part 4. Acrididae incertae sedis and addendum to Catantopinae. Annals and Magazine of Natural History (11) 11:359383.

Figure captions

Figure 1. Location map of the study area.

Figure 2. Stratigraphic column of the fossiliferous deposits of the Babaheidar lagersttate.

Figure 3. Orthoptera Acrididae, specimen IUDG 16. Photograph of imprint. Scale bar: 10 mm.

Figure 4. Orthoptera Acrididae, specimen IUDG 16. Photograph of counter-imprint. Scale bar: $10 \mathrm{~mm}$.

Figure 5. Hymenoptera: Formicidae (possibly Myrmicinae). 1. UIDGA1 (imprint); 2-3. UIDGA3-4 (imprint and counter-print); 4. UIDGA5 (imprint); 5. UIDGA7 (imprint); 6. UIDGA6 (counter-print of UIDGA5); 7-8. UIDGA9-10 (imprint and counter-print); 9. UIDGA8 (counter-print of UIDGA7); 10-11. UIDGA2 (counter-print of UIDGA1); 12. UIDGA11; 13. UIDGA12; 14. UIDGA13; 15-16 (UIDGA14-15) (imprint and counter-print). 


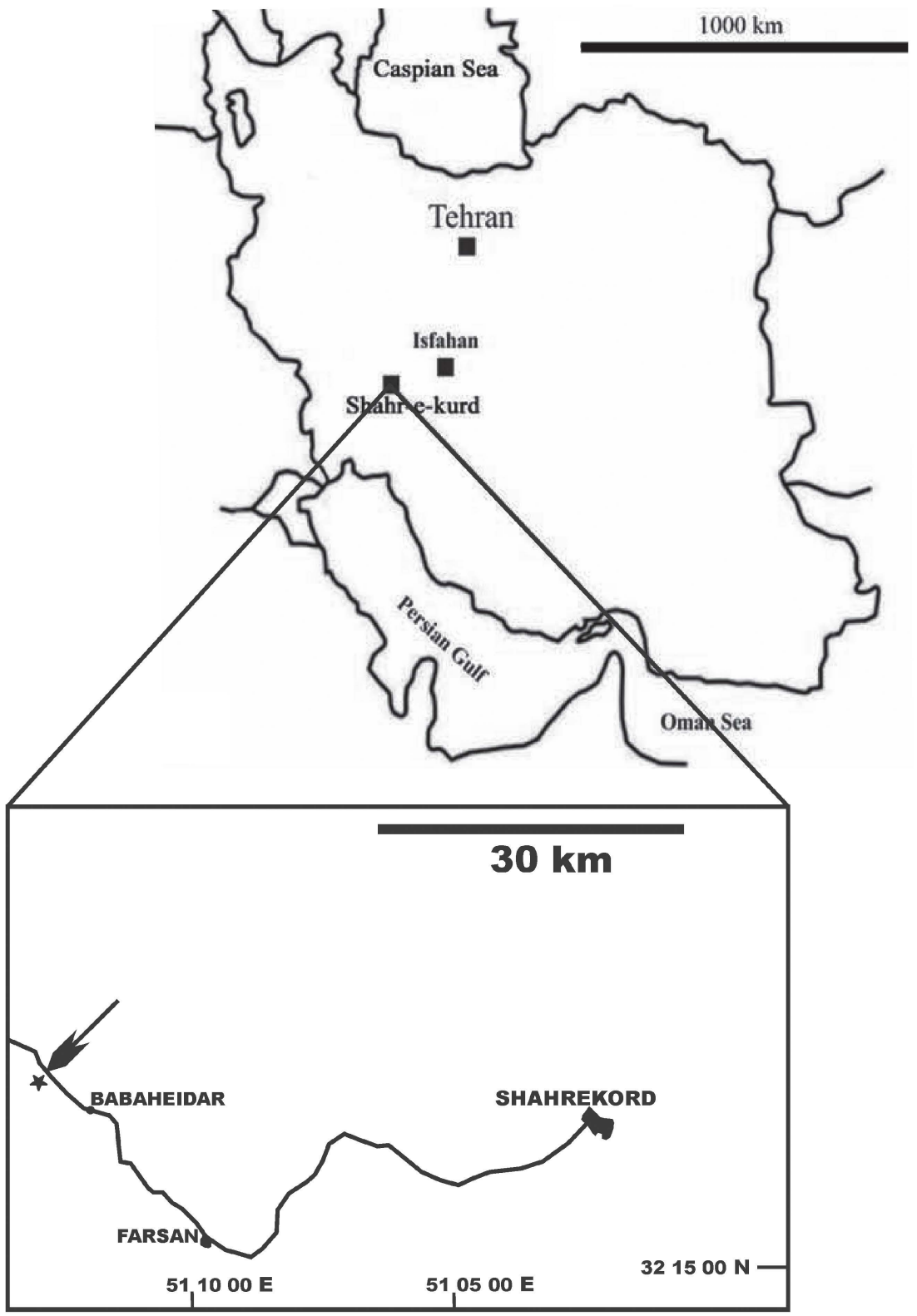




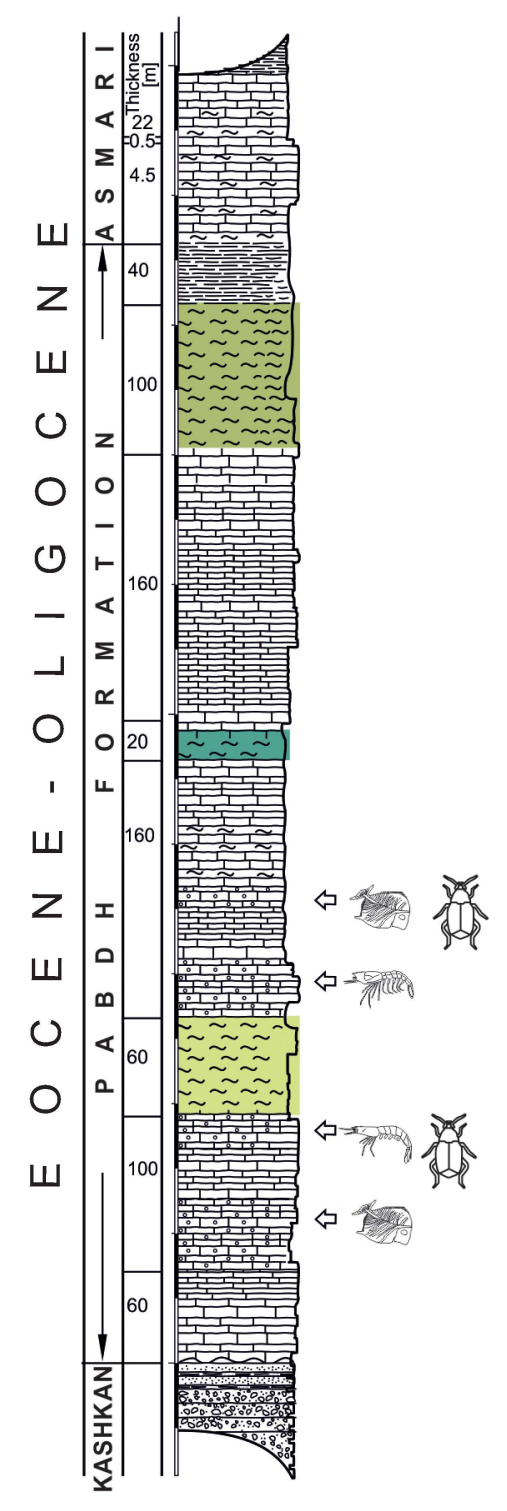

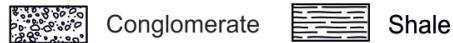

뭉

Marly limestone with foraminifers, fish remains and crustaceans ₹ Marl 


